Journal of Research in Interprofessional

Practice and

Education

Vol. 1.3

December, 2010

\section{Assessing Student Attitudes as a Result of Participating in an Interprofessional Healthcare Elective Associated with a Student-Run Free Clinic}

\author{
Sarah Shrader, PharmD, Amy Thompson, PharmD, \\ Wanda Gonsalves, MD
}

\begin{abstract}
Background: An interprofessional elective using a student-run clinic can introduce students to professional roles, collaborative patient care, and health disparities.

Methods and Findings: Students from four professions (pharmacy, medicine, physician assistant, and physical therapy) participated in a service-learning elective where they received weekly didactic lectures and provided healthcare in a student-run free clinic. Additional interprofessional activities included a quality improvement project and a case presentation. Students were administered anonymous surveys before and after the elective to assess changes in their attitudes toward interprofessional teamwork. A total of 93 and 74 students completed the pre-survey and post-survey, respectively. After participating in the elective, significantly more students reported working in interprofessional teams and understood the role of physician assistants. The majority of other attitudes about interprofessional collaboration and professional roles were sustained or improved after the elective.

Conclusion: An interprofessional service-learning elective using didactic and experiential learning in an interprofessional, student-run free clinic sustained or improved student attitudes toward interprofessional teamwork. The elective had a significant impact on increased student experience working in interprofessional healthcare teams and increased understanding of health professions' roles. Continued assessment of the impact on student behaviours and patient outcomes is warranted.
\end{abstract}

Keywords: Interprofessional; Service-learning; Student-run free clinic; Attitudes; Didactic

\section{Introduction}

Interprofessional education (IPE) and practice are increasingly called upon as essential competencies in health professions education. IPE occurs when two or more professions learn with, from, and about each other to improve collaboration and the quality of care [1]. The Institute of Medicine: Bridge to Quality report endorses the movement toward an interprofessional approach to patient care [2]. Additionally, many health professions organizations, such as the Association of American Medical Colleges and the American Association of Colleges of Pharmacy (AACP), include interprofessional health education and practice as strategic areas in which the organization and members should engage. AACP has further endorsed the value of interprofessional teamwork by including it as a criterion in AACP accreditation standards.

Creating optimal IPE experiences in undergraduate health professions' education is no easy task. Determining how the interprofessional education content is delivered 
Interprofessional Healthcare Elective and Student-Run Free Clinic

Shrader, Thompson, \& Gonsalves

Journal of Research in Interprofessional Practice and Education

Vol. 1.3

December, 2010
Journal of Research in Interprofessional Practice and Education

(e.g., classroom didactic-based, case-based, experiential) has been researched and no clear results have been published [3]. Most experts agree that a combination of these curricular components may be ideal for the integration of interprofessional education into the curriculum. Common competencies for IPE include understanding team organization/function, assessing and enhancing team performance, communicating with team members, demonstrating leadership, resolving conflict and building consensus, and setting common patient care goals [4]. IPE experiences should be designed to achieve these competencies.

There are successful models of IPE reported in the literature. Reviews of some key evidence suggest it is important that IPE authentically reflects current and future practice models and principles of adult learning [3,5]. There is evidence that IPE has positive or neutral effects on student attitudes and behaviour; however, rigorous examples and outcomes are lacking $[3,6]$. Service-learning using a student-run clinic is an example. There are models of interprofessional student-run free clinics; however, limited information on these interprofessional clinics has been published. Continued publication of IPE examples and outcomes is needed to establish the impact of this educational model for the future. The study described in this article may serve as such a model.

The objectives of this study were two-fold: 1) to describe the interprofessional elective, including the didactic course and patient care activities at a student-run free clinic, and 2) to evaluate changes in student attitudes toward interprofessional healthcare, professional roles, and teamwork before and after participation in the interprofessional elective.

\section{Methods}

\section{Context}

The Medical University of South Carolina (MUSC) is a free-standing academic health sciences centre located in Charleston, South Carolina. MUSC consists of six colleges, including dental, health professions and graduate studies, medicine, nursing, and pharmacy. Currently MUSC is engaged in a ten-year interprofessional education initiative, "Creating Collaborative Care." This is a plan to promote an institutional culture, learning environment, and infrastructure that enhances MUSC graduates' abilities to participate as effective team members in interprofessional collaborative healthcare delivery or research.

\section{Interprofessional service-learning elective}

The interprofessional service-learning elective, "Caring for the Community," was developed in 2005 and offered to 50 students involving four professions ( 25 first-/second-year medical students, 15 first-year physician assistant students, 5 third-year pharmacy students, 5 first-year physical therapy students) each semester at MUSC. The course was offered as an interprofessional two credit-hour elective graded by pass/fail method. The didactic portion of the elective consisted of 11 lectures held one evening each week for two hours. 
220

Interprofessional Healthcare Elective and Student-Run Free Clinic

Shrader, Thompson, \& Gonsalves

Journal of Research in Interprofessional Practice and Education

Vol. 1.3

December, 2010
Table 1

\section{Interprofessional didactic lecture sessions*}

\begin{tabular}{|c|c|c|}
\hline & Class Topic & Description \\
\hline Session 1 & Elective Orientation & $\begin{array}{l}\text { - Clinic and didactic orientation } \\
\text { - Introduction to service-learning, health disparities and } \\
\text { interprofessional healthcare lecture } \\
\text { - Students introduced to interprofessional teams }\end{array}$ \\
\hline Session 2 & Medical Records Workshop & $\begin{array}{l}\text { - Lecture on medical record documentation and prescriptions } \\
\text { - Interprofessional teams provided with clinical case and required } \\
\text { to write SOAP note and prescriptions }\end{array}$ \\
\hline Session 3 & $\begin{array}{l}\text { Basic Office Procedures } \\
\text { Workshop I }\end{array}$ & $\begin{array}{l}\text { - Interprofessional groups practice phlebotomy and injection } \\
\text { techniques on group members }\end{array}$ \\
\hline Session 4 & $\begin{array}{l}\text { Basic Office Procedures } \\
\text { Workshop II }\end{array}$ & $\begin{array}{l}\text { - Interprofessional groups rotate to stations and have active learn- } \\
\text { ing demonstration on: pelvic exam, diabetes exam/equipment, } \\
\text { respiratory inhalers, electrocardiogram equipment, laboratory } \\
\text { test (e.g., urinalysis) }\end{array}$ \\
\hline Session 5 & $\begin{array}{l}\text { Community Health and } \\
\text { Quality Improvement } \\
\text { Projects }\end{array}$ & $\begin{array}{l}\text { - Didactic lecture } \\
\text { - Interprofessional student groups assigned quality improvement } \\
\text { project for clinic and begin to brainstorm ideas }\end{array}$ \\
\hline Session 6 & $\begin{array}{l}\text { Interprofessional Group } \\
\text { Work Period }\end{array}$ & $\begin{array}{l}\text { - Timeline and quality improvement project proposals due for } \\
\text { each interprofessional group } \\
\text { - Interprofessional patient cases from clinic identified and group } \\
\text { critically evaluates the clinical case and reflects on interprofes- } \\
\text { sional care }\end{array}$ \\
\hline Session 7 & $\begin{array}{l}\text { Interprofessional Patient } \\
\text { Case Presentations }\end{array}$ & $\begin{array}{l}\text { - Interprofessional groups present the patient case encountered } \\
\text { at the clinic and provide thorough clinical recommendations } \\
\text { (see above) } \\
\text { - Group reflections on interprofessional healthcare teams }\end{array}$ \\
\hline Session 8 & $\begin{array}{l}\text { Part 1: This is What I Do! } \\
\text { Part 2: Movie Night: } \\
\text { Unnatural Causes }\end{array}$ & $\begin{array}{l}\text { - Student representatives from each profession share what their } \\
\text { profession does, stereotypes, highlights of training program, } \\
\text { and scopes of practice } \\
\text { - In-class discussion and Q\&A session about interprofessional roles } \\
\text { - Watch highlights of movie and in-class discussion of healthcare } \\
\text { disparities and social determinants of health }\end{array}$ \\
\hline Session 9 & $\begin{array}{l}\text { Part 1: Computer } \\
\text { Scavenger Hunt for Social } \\
\text { and Community Referral } \\
\text { Services } \\
\text { Part 2: Domestic Violence }\end{array}$ & $\begin{array}{l}\text { - Interprofessional groups provided with clinical cases needing } \\
\text { community/social resources and will need to “hunt” for help } \\
\text { using Internet } \\
\text { - Interactive lecture on domestic violence and information } \\
\text { provided about My Sisters House Organization }\end{array}$ \\
\hline Session 10 & $\begin{array}{l}\text { Interprofessional Group } \\
\text { Work Period }\end{array}$ & $\begin{array}{l}\text { - Interprofessional groups provided in-class time to finish up } \\
\text { quality improvement projects }\end{array}$ \\
\hline Session 11 & $\begin{array}{l}\text { Interprofessional Group } \\
\text { Quality Improvement } \\
\text { Project Presentations }\end{array}$ & $\begin{array}{l}\text { - Interprofessional groups present quality improvement project } \\
\text { findings in class via PowerPoint presentations }\end{array}$ \\
\hline
\end{tabular}

*Each session is 2 hours. 
Interprofessional Healthcare Elective and Student-Run Free Clinic

Shrader, Thompson, \& Gonsalves

Journal of Research in Interprofessional Practice and Education

Vol. 1.3

December, 2010
Students in the elective were assigned to small interprofessional groups (five members) and they participated in weekly lectures involving many active learning strategies. The weekly lectures focused on basic clinical skills, issues with the uninsured and healthcare disparities, social resources, and interprofessional teamwork (Table 1). In addition to the lectures, each interprofessional student group participated in a quality improvement project related to the student-run free clinic, with each member of the profession contributing to the project and teaching other members from their own healthcare perspective (Table 2). Each student group was also

Table 2

\section{Selected examples of interprofessional quality improvement projects for the clinic}

\begin{tabular}{|l|l|}
\hline Project Title & Summary \\
\hline $\begin{array}{l}\text { Improving Vaccination Rates for Patients } \\
\text { with Diabetes }\end{array}$ & $\begin{array}{l}\text { Obtained state-funded influenza vaccines and developed clinic policy } \\
\text { and protocol for vaccine administration by students }\end{array}$ \\
\hline $\begin{array}{l}\text { Cost-benefit Analysis of Obtaining Point- } \\
\text { of-Care Hemoglobin A1c Machine }\end{array}$ & $\begin{array}{l}\text { Cost-benefit analysis performed and recommendation to purchase } \\
\text { point-of-care A1c machine for use at clinic by students }\end{array}$ \\
\hline Improving Smoking Cessation Rates & $\begin{array}{l}\text { Surveys administered to patients to determine interest in smoking } \\
\text { cessation modalities (as a result, smoking cessation group classes are } \\
\text { under development) }\end{array}$ \\
\hline Improving Diabetes Foot Exams & $\begin{array}{l}\text { Survey administered to students to determine knowledge regarding } \\
\text { comprehensive diabetes foot exam (results were poor) so an educa- } \\
\text { tional diabetes foot exam station was created and implemented in } \\
\text { basic office procedures workshop }\end{array}$ \\
\hline
\end{tabular}

responsible for presenting an interprofessional patient case encountered in the student-run free clinic; presentations incorporated clinical and social issues highlighting interprofessional patient management. Additionally, each student was required to provide patient care at the clinic five evenings per semester (clinic details are discussed below). Each week the students emailed reflections to course directors; many of them were related to their interprofessional experiences in the clinic and didactic sessions. A few reflections were selected and presented at the weekly didactic sessions. Implementation of these activities within the elective course fulfilled the suggested IPE competencies [4].

The didactic course was co-directed by three interprofessional medicine and pharmacy faculty that hold positions in the colleges of pharmacy, health professions, and medicine at MUSC. The didactic sessions were team-taught by a variety of interprofessional faculty and preceptors including pharmacists, physician assistants, and physicians. The directors of the elective felt that it was important to expose students to a variety of interprofessional faculty members as well as students. 
222

Interprofessional Healthcare Elective and Student-Run Free Clinic

Shrader, Thompson, \& Gonsalves
Journal of Research in Interprofessional Practice and Education

Vol. 1.3

December, 2010
Table 3

Interprofessional healthcare team dynamics at the student-run free clinic.*

\begin{tabular}{|c|c|c|}
\hline Usual Step & Interprofessional Action & Comment \\
\hline $\begin{array}{l}\text { Team } \\
\text { Introduction and } \\
\text { Planning }\end{array}$ & $\begin{array}{l}\text { Interprofessional teams formed (medical } \\
\text { student(s), pharmacy student, physician } \\
\text { assistant student) at the beginning of } \\
\text { evening before clinical visits begin }\end{array}$ & $\begin{array}{l}\text { Teams are encouraged to discuss roles and expecta- } \\
\text { tions for each patient visit (e.g., first-year medical } \\
\text { student conduct history, second-year medical stu- } \\
\text { dent and physician assistant student conduct physi- } \\
\text { cal exam, pharmacy student conduct medication } \\
\text { history, fourth-year medical student supervise) }\end{array}$ \\
\hline Patient Visit & Interprofessional team conduct patient visit & \\
\hline $\begin{array}{l}\text { Patient } \\
\text { Assessment } \\
\text { and Plan }\end{array}$ & $\begin{array}{l}\text { Interprofessional team develop assess- } \\
\text { ment and patient-specific care plan out- } \\
\text { side of examination room }\end{array}$ & $\begin{array}{l}\text { Interprofessional discussions occur and all team } \\
\text { members encouraged to participate } \\
\text { Team determines additional tests, referrals, pre- } \\
\text { scriptions, and patient education that is needed }\end{array}$ \\
\hline $\begin{array}{l}\text { Patient } \\
\text { Presentation to } \\
\text { Attending } \\
\text { Preceptors }\end{array}$ & $\begin{array}{l}\text { Interprofessional team presents patient, } \\
\text { assessment and plan to preceptors }\end{array}$ & $\begin{array}{l}\text { Further input and discussion occurs from the } \\
\text { preceptor stand-point (e.g., attending physician } \\
\text { asks students questions about diagnosis, attend- } \\
\text { ing pharmacist asks medication related ques- } \\
\text { tions), and they both offer teaching points to } \\
\text { the student groups }\end{array}$ \\
\hline $\begin{array}{l}\text { Attending } \\
\text { Preceptors } \\
\text { Examine Patient } \\
\text { and Develop } \\
\text { Assessment and } \\
\text { Plan }\end{array}$ & $\begin{array}{l}\text { Check to ensure accuracy of } \\
\text { student team }\end{array}$ & $\begin{array}{l}\text { Agree with interprofessional student team plan } \\
\text { or alter plan as necessary }\end{array}$ \\
\hline $\begin{array}{l}\text { Interprofessional } \\
\text { Team Finish Visit }\end{array}$ & $\begin{array}{l}\text { Typical team actions include } \\
\text { - first-year medical student and phar- } \\
\text { macy student write prescriptions and } \\
\text { counsel the patient } \\
\text { - second-year medical student and physi- } \\
\text { cian assistant student obtain blood work } \\
\text { - first-year medical student writes refer- } \\
\text { ral for specialty service needed } \\
\text { - pharmacy student begins to counsel on } \\
\text { chronic disease /lifestyle modifications } \\
\text { - all students wrap-up visit and answer } \\
\text { questions }\end{array}$ & $\begin{array}{l}\text { The actions are based upon the needs of the } \\
\text { specific patient and will vary }\end{array}$ \\
\hline $\begin{array}{l}\text { Interprofessional } \\
\text { Team Document } \\
\text { Visit }\end{array}$ & $\begin{array}{l}\text { Interprofessional team documents in } \\
\text { medical record } \\
\text { (e.g., SOAP note, update medication } \\
\text { record) }\end{array}$ & $\begin{array}{l}\text { The student team often uses this time and con- } \\
\text { tinues to learn from each other about the } \\
\text { patient visit } \\
\text { The team debriefs lessons learned and clarify } \\
\text { issues brought up during the patient visit and } \\
\text { with preceptors }\end{array}$ \\
\hline
\end{tabular}

*Times for each patient visit vary (average time from start to finish usually 45 minutes); each interprofessional team typically cares for 2-3 patients each night 


\section{3}

Interprofessional Healthcare Elective and Student-Run Free Clinic

Shrader, Thompson, \& Gonsalves

Journal of Research in Interprofessional Practice and Education

Vol. 1.3 December, 2010

\section{Interprofessional student-run free clinic}

The student-run free clinic was initially developed by medical students in 2005 and expanded to include other professions in 2007. The free clinic partnered with East Cooper Community Outreach program, a local organization with a mission of helping neighbours in need and providing emergency disaster relief through cooperation with other organizations and agencies. Clinic space was provided by the MUSC Department of Family Medicine satellite clinic, including access to their medical equipment. The clinic operates three evenings per week from 6-10 pm and accepts up to 10 patients per night.

All students enrolled in the interprofessional elective course provided patient care five evenings during the semester. These students worked in interprofessional healthcare teams from start to finish of the patient encounter. Each interprofessional team was made up of a pre-clinical medical or physician assistant student, a pharmacy student, and an upper-level medical student volunteer who was not enrolled in the elective. These teams conducted a patient interview and presented their findings, assessment, and plans to attending preceptors (physicians, physician assistants, nurse practitioners, and pharmacists). They also provided patient education and documented details of the visit in the medical record. The attending preceptors modeled competent interprofessional team behaviours and encouraged positive team interactions among the students. Clinical services provided at the student-run free clinic included primary care (medical, pharmacy, physician assistant), $\mathrm{OB} / \mathrm{GYN}$, psychiatry, physical therapy, and group diabetes education. Examples of the interprofessional team dynamics for a typical primary care visit are provided in Table 3.

\section{Assessment}

Student attitudes toward interprofessional healthcare, professional roles, and teamwork were assessed using an electronic survey (Survey Monkey, Inc.). Students enrolled in the elective (data collected spring 2008, fall 2008, spring 2009) were encouraged to complete the anonymous survey using a five-point Likert scale. The survey was sent to the students one week prior to the first class to assess student attitudes before the elective. The same survey was sent to the students one week after the completion of the elective.

The investigators developed a 17-question survey (Appendix 1) that was piloted to students enrolled in the elective in an earlier semester and then revised based on student and faculty feedback. The final survey used in the study included eight questions from the Readiness for Interprofessional Learning Scale (RIPLS). The RIPLS is a validated 19-statement scale assessing 3 sub-factors: teamwork and collaboration, professional identity, and roles and responsibility for undergraduate health professions' education [7-8]. Some questions were modified or removed from the original RIPLS scale to be more applicable to the students specifically in the elective. The remaining nine questions, which were developed by the investigators, assessed student confidence in working on interprofessional teams, in the role of interprofessional teamwork in the future, and in understanding the roles of the specific health 
Interprofessional Healthcare Elective and Student-Run Free Clinic

Shrader, Thompson, \& Gonsalves

Journal of Research in Interprofessional Practice and Education

Vol. 1.3 December, 2010

\section{Journal of Research in Interprofessional Practice and Education}

professions' students enrolled in the course. The survey items developed by the investigators were not validated.

\section{Statistical analysis}

Statistical analyses were performed using the Microsoft Excel statistical package. Demographic data were analyzed using descriptive statistics. Pre-elective survey results for all students completing the elective in any semester were combined for analysis, as were the results of the post-elective survey. Overall scores on each RIPL sub-factor were not assessed; each survey item was assessed individually using the independent Student's $t$-test.

The study was approved by the Institutional Review Board at MUSC.

\section{Results}

A total of 113 students were enrolled and completed the IPE elective over three semesters: 67 medical students, 41 physician assistant students, 15 pharmacy students, and 10 physical therapy students. Of the students enrolled, 93 (82\%) completed the pre-survey and 74 (65\%) completed the post-survey.

There were no differences between pre- and post-survey results for any of the RIPLS questions. However, there were significant differences between pre- and postsurvey results for the investigator-developed survey items centred on understanding professional roles. Significant improvements were seen in attitudes toward "increased experience working in interprofessional healthcare teams" and "understanding roles and responsibilities of different health professions' team members." There was a significant increase in the degree of experience working with students from another profession in an interprofessional team after the elective $(M=4.4 ; S D$ $=0.8)$ compared with before the elective $(M=3.6 ; S D=1.1) ; t(\mathrm{df})=5.68(165), p<$ 0.0001 . Significantly more students understood the role of physician assistants within an interprofessional team after the elective $(M=4.2, S D=0.9)$ compared with before the elective $(M=3.9, S D=0.9) ; t(\mathrm{df})=2.43(164), p=0.02$. There was a trend toward increased understanding of the role of pharmacists within an interprofessional team, but it did not reach statistical significance (pre-elective $M=4.1, S D=$ 0.8 ; post-elective $M=4.4, S D=0.8 ; t(\mathrm{df})=1.87(165), p=0.06)$. Understandings of the roles of medicine and physical therapy did not significantly change but remained high before and after the elective (Table 4).

\section{Discussion}

Implementation of an interprofessional service-learning elective that included didactic and service experience at a student-run free clinic sustained or improved student attitudes about interprofessional roles, healthcare, and teamwork. Attitudinal outcomes evaluated included teamwork and collaboration, professional identity, and roles and responsibility using a modified version of the RIPLS survey. Incorporation of several methods (including didactic sessions, group projects, and clinical experiences) to teach the fundamentals of interprofessional teamwork to a 
225

Interprofessional Healthcare Elective and Student-Run Free Clinic

Shrader, Thompson, \& Gonsalves
Journal of Research in Interprofessional

Practice and

Education

Vol. 1.3

December, 2010
Table 4

Student survey results: interprofessional attitudes

\begin{tabular}{|c|c|c|c|}
\hline Question & $\begin{array}{c}\text { Pre- } \\
\text { Elective } \\
\text { (mean) }\end{array}$ & $\begin{array}{l}\text { Post- } \\
\text { Elective } \\
\text { (mean) }\end{array}$ & $\begin{array}{c}p- \\
\text { value }^{*}\end{array}$ \\
\hline \multicolumn{4}{|l|}{ Investigator-developed Survey Items } \\
\hline $\begin{array}{l}\text { I have worked with students from other health professions in an interprofes- } \\
\text { sional team. }\end{array}$ & 3.6 & 4.4 & $<0.001$ \\
\hline $\begin{array}{l}\text { I am confident in my abilities to effectively work within an interprofessional } \\
\text { healthcare team to develop a realistic and appropriate patient care plan. }\end{array}$ & 4.2 & 4.4 & 0.12 \\
\hline I understand the respective role of medicine within an interprofessional team. & 4.2 & 4.4 & 0.19 \\
\hline I understand the respective role of physician assistants within an interprofessional team. & 3.9 & 4.2 & 0.01 \\
\hline I understand the respective role of physical therapy within an interprofessional team. & 4.1 & 4.1 & 0.45 \\
\hline I understand the respective role of pharmacy within an interprofessional team. & 4.1 & 4.4 & 0.06 \\
\hline It is important to interact with teachers and preceptors from other healthcare professions. & 4.4 & 4.5 & 0.50 \\
\hline Using interprofessional teams to deliver quality healthcare is essential for the future. & 4.5 & 4.6 & 0.57 \\
\hline $\begin{array}{l}\text { I am going to work in an environment that fosters interprofessional teamwork } \\
\text { to deliver patient care in the future. }\end{array}$ & 4.3 & 4.4 & 0.72 \\
\hline \multicolumn{4}{|l|}{ RIPLS Survey Items } \\
\hline Clinical problem-solving skills should only be learned with students from my own discipline. & 1.6 & 1.6 & 0.80 \\
\hline $\begin{array}{l}\text { I have to acquire more knowledge and skills than other students in other health- } \\
\text { care disciplines. }\end{array}$ & 2.9 & 2.7 & 0.19 \\
\hline $\begin{array}{l}\text { There is little overlap between my role and that of other students belonging to } \\
\text { other healthcare disciplines. }\end{array}$ & 1.7 & 1.7 & 0.67 \\
\hline $\begin{array}{l}\text { Shared learning and working within an interprofessional team will help me } \\
\text { communicate better with patients and healthcare professionals. }\end{array}$ & 4.6 & 4.5 & 0.76 \\
\hline $\begin{array}{l}\text { Shared learning and working within an interprofessional team will increase my } \\
\text { ability to understand clinical problems. }\end{array}$ & 4.5 & 4.4 & 0.86 \\
\hline $\begin{array}{l}\text { Shared learning and working within an interprofessional team will help me be a } \\
\text { more effective member of a healthcare team in the future. }\end{array}$ & 4.7 & 4.5 & 0.32 \\
\hline $\begin{array}{l}\text { Shared learning and working within an interprofessional team will help me } \\
\text { understand my own limitations. }\end{array}$ & 4.4 & 4.5 & 0.59 \\
\hline $\begin{array}{l}\text { Patients ultimately benefit if students and healthcare professionals work in } \\
\text { interprofessional teams to solve patient problems. }\end{array}$ & 4.6 & 4.6 & 0.71 \\
\hline
\end{tabular}

Evaluated using Likert scale 1 through 5: $1=$ strongly disagree, $5=$ strongly agree

${ }^{*} P$-values were derived from independent sample $t$-tests. These $p$-values are conservative estimates of the true pre-post differences, given that many of the survey responses were by the same individuals. See text for a more thorough explanation. 
226

Interprofessional Healthcare Elective and Student-Run Free Clinic

Shrader, Thompson, \& Gonsalves

Journal of Research in Interprofessional Practice and Education

Vol. 1.3 December, 2010 group of health professions' students, including medicine, pharmacy, physician assistant, and physical therapy, was effective.

While there are several examples of IPE models in the literature, many lack outcome data and are merely descriptive in nature. The most recent Cochrane Review concluded that IPE has positive or neutral outcomes on professional practice and patient care, but more rigorous evaluations are needed [6]. Another systematic review identified and analyzed data from additional IPE studies. The review concluded that IPE is well received and may change attitudes and patient outcomes, but more conclusive evidence is warranted [3]. Descriptions of IPE initiatives specifically in undergraduate health professions' education are more limited. In addition, the ideal educational settings for these activities have not been established. Experts have advocated creating IPE activities that increase in complexity over time using cooperative and experiential learning [9]. The interprofessional elective described in this article serves as an example of this model.

There are some additional undergraduate health professions' IPE models reported in the literature. A required IPE session was provided to health professions' students in Canada. The session involved discussion about a patient case and discharge scenario. Students reported significant gains in understanding the importance of teamwork and the roles of other professions [10]. A required IPE experience using a complex standardized patient has been reported. Nursing, medical, and pharmacy students developed an interprofessional care plan for the standardized patient. Reflective comments before and after the experience captured by only one profession (pharmacy) were reported, and students' awareness of other professions' roles increased [11]. The longitudinal evaluation of a three-year IPE curriculum using a variety of curricular modalities delivered to medical, nursing, pharmacy, and social work students was reported. There was no significant change in attitudes regarding interprofessional collaboration over time; however, attitudes remained positive throughout the longitudinal evaluation period [12]. Our findings add to the body of evidence assessing student attitudes and awareness about interprofessional roles, teamwork, and healthcare.

In contrast to many of the models discussed, our findings used aspects of actual direct patient care. Developing IPE activities within student-run free clinics is a way to promote interprofessional collaboration in an experiential setting. Student-run free clinics are increasing in popularity, and a majority of medical schools in the United States are affiliated with these clinics. Traditionally, these clinics have been initiated and run by medical students focusing on acute and chronic healthcare delivery [13]. Increased involvement of other health professions in student-run free clinics has evolved. Student-run free clinics in Washington and California provided interprofessional clinic services in addition to health education strategies to patients. Students involved with the clinics were also involved in a didactic course and various reflection exercises; outcomes associated with these experiences were not reported [14-15]. The literature on interprofessional student-run free clinics is descriptive, and evaluation of the effects of this type of IPE experience on student attitudes has not been widely published. Our findings move beyond descriptive 
227

Interprofessional Healthcare Elective and Student-Run Free Clinic

Shrader, Thompson, \& Gonsalves

Journal of Research in Interprofessional Practice and Education

Vol. 1.3 December, 2010 commentary and assess actual changes in student attitudes associated with their experiences in an interprofessional student-run free clinic.

Our interprofessional elective affiliated with a didactic course and student-run free clinic adds to the current evidence of undergraduate IPE activities. The elective course is applicable to the students' current and future settings, which has been identified as a critical element to the success of IPE. The elective course uses a variety of methods to promote interprofessional collaborations through cooperative and experiential learning; examples include an interprofessional quality improvement project for the clinic, presentation of an interprofessional patient case, and providing care to patients in interprofessional teams at the student-run free clinic. The course fulfills desired IPE competencies that have been published in the literature. In addition, it was developed, directed, and team-taught by interprofessional faculty who model interprofessional collaboration for the undergraduate students and assure that all health professions' interests are represented. A large number of students from four professions are represented in our sample with a relatively high response rate for a voluntary survey. Most importantly, the authors have gone beyond description of the interprofessional course. Student attitudes were assessed using a survey that was modified from existing validated instruments in the literature, and outcomes were analyzed with appropriate statistical methods. The course is described in detail and could be implemented at many universities, especially where student-run free clinics are already established.

Despite what this course adds to the current body of literature, it is not without limitations. Because many of the pre- and post-elective surveys were completed by the same individuals, and because our survey was completed anonymously (thus making it impossible to conduct paired $t$-tests), the $p$-values obtained from the $t$ tests are actually conservative estimates. In other words, if we had been able to link subjects' pre- and post-elective surveys and perform a paired $t$-test, the resulting $p$ values would have been smaller than what was observed in the independent sample $t$-test. In addition, an equal representation of each health profession was not accounted for, and survey results were not separated by profession to determine if there were differences among the groups. This course was an elective, and students that enrolled may have already had positive attitudes regarding interprofessional collaborations. Not all students enrolled in the elective participated in the survey because it was not a mandatory portion of the elective. The study design used a before and after approach; a more rigorous study design would have included a control group. However, having a control group was not feasible in this educational research because all students enrolled in the course needed the same experience. Assessment strategies only focused on changes in attitudes using a modified survey instrument that was applicable to the elective course; however, many of the questions on the survey were not validated. It is unknown which components of the interprofessional elective contributed to the changes in attitudes seen in our course. Further studies are needed to determine what makes an interprofessional elective successful. Finally, long-term assessment beyond student attitudes is needed to determine if this experience changes student behaviour or patient outcomes. 
228

Interprofessional Healthcare Elective and Student-Run Free Clinic

Shrader, Thompson, \& Gonsalves

Journal of Research in Interprofessional Practice and Education

Vol. 1.3

December, 2010

\section{Summary}

An interprofessional service-learning elective provided to students from four professions (medicine, pharmacy, physician assistant, and physical therapy) improved or sustained positive attitudes regarding interprofessional roles, healthcare, and teamwork. The most significant impact was on increased student experience working in interprofessional healthcare teams and increased understanding of health professions' roles. Future assessment is warranted to determine if an interprofessional elective experience can change student behaviours or improve patient outcomes.

\section{Acknowledgements}

The authors would like to thank Drs. Amy Blue, Mary Mauldin, and Paul Nietert for their assistance, input, and support while writing this manuscript. The authors would also like to acknowledge that this project was supported by Award Number UL1RR029882 from the National Center for Research Resources. The content is solely the responsibility of the authors and does not necessarily represent the official views of the National Centre for Research Resources or the National Institutes of Health.

\section{References}

1. Centre--for --the--Advañementent--of--Interporofessional Education. (2010). URL: 'http://www.caipe.org.uk/about-us/defining-ipe/'[May 1, 2009].

2. Greiner, A.C., \& Knebel, E. (Eds.). (2003). Health professions education: A bridge to quality. Washington, DC: National Academy Press.

3. Hammick, M., Freeth, D., Koppel, I., Reeves, S., \& Barr, H. (2007). A best evidence systematic review of interprofessional education. Medical Teacher, 29, 735-751 [DOI: 10.1080 /01421590701682576].

4. Buring, S., Bhushan, A., Brueseker, A., Conway, S., Duncan-Hewitt, W., et al. (2009). Interprofessional education: Definitions, student competencies, and guidelines for implementation. American Journal of Pharmaceutical Education, 73, article 59.

5. Page, R., Hume, A., Trujillo, J., Leader, G., Vardeny, O., et al. (2009). Interprofessional education : Principles and application. A framework for clinical pharmacy. Pharmacotherapy, 29(3), 145-164.

6. Reeves, S., Zwarenstein, M., Goldman, J., Barr, H., Freeth, D., et al. (2008). Interprofessional education: Effects on professional practice and health care outcomes. Cochrane Database Systematic Review, CD002213.

7. Parsell, G., \& Bligh, J. (1999). The development of a questionnaire to assess the readiness of health care students for interprofessional learning (RIPLS). Medical Education, 33, 95-100.

8. Horsburgh, M., Lamdin, R., \& Williamson, E. (2001). Multiprofessional learning: The attitudes of medical, nursing and pharmacy students to shared learning. Medical Education, 35, 876-83.

9. D’Eon, M. (2005). A blueprint for interprofessional learning. Journal of Interprofessional Care, 19, 49-59 [DOI: 10.1080/13561820512331350227].

10. Cameron, A., Ignjatovic, M., Langlois, S., Dematteo, D., DiProspero, L., et al. (2009). An interprofessional education session for first-year health science students. American Journal of Pharmaceutical Education, 73, article 62.

11. Westberg, S., Adams, J., Thiede, K., Stratton, T., \& Bumgardner, M. (2006). An interprofessional activity using standardized patients. American Journal of Pharmaceutical Education, 70, article 34.

12. Curran, V., Sharpe, D., Flynn, K., \& Button, P. (2010). A longitudinal study of the effect of an interprofessional education curriculum on student satisfaction and attitudes toward interprofessional teamwork and education. Journal of Interprofessional Care, 24(1), 41-52.

13. Simpson, B., \& Long, J. (2007). Medical student-run health clinics: Important contributors to patient care and medical education. Society of General Internal Medicine, 22, 352-356.

14. Moskowitz, D., Glasco, J., Johnson, B., \& Wang, G. (2006). Students in the community: An interprofessional student-run free clinic. Journal of Interprofessional Care, 20, 254-259 [DOI: $10.1080 / 13561820600721091]$.

15. Beck, E. (2005). The UCSD Student-Run Free Clinic Project: Transdisciplinary health professional education. Journal of Health Care for the Poor and Underserved, 16, 207-19. 
229

Interprofessional Healthcare Elective and Student-Run Free Clinic

Shrader, Thompson, \& Gonsalves
Journal of Research in Interprofessional Practice and Education

Vol. 1.3

December, 2010

\section{Appendix 1 Interprofessional Student Attitude Survey}

1. Clinical problem-solving skills should only be learned with students from my own discipline.* Strongly Disagree Disagree Neutral Agree Strongly Agree
1
2
3
4
5

2. I have to acquire more knowledge and skills than other students in other healthcare disciplines.*

$\begin{array}{ccccc}\text { Strongly Disagree } & \text { Disagree } & \text { Neutral } & \text { Agree } & \text { Strongly Agree } \\ 1 & 2 & 3 & 4 & 5\end{array}$

3. There is little overlap between my role and that of other students belonging to other healthcare disciplines.*

$\begin{array}{ccccc}\text { Strongly Disagree } & \text { Disagree } & \text { Neutral } & \text { Agree } & \text { Strongly Agree } \\ 1 & 2 & 3 & 4 & 5\end{array}$

4. I have worked with students from other health professions in an interprofessional team.

Strongly Disagree Disagree Neutral Agree Strongly Agree

$\begin{array}{lllll}1 & 2 & 3 & 4 & 5\end{array}$

5. I am confident in my abilities to effectively work within an interprofessional healthcare team to develop a realistic and appropriate patient care plan.

$\begin{array}{ccccc}\text { Strongly Disagree } & \text { Disagree } & \text { Neutral } & \text { Agree } & \text { Strongly Agree } \\ 1 & 2 & 3 & 4 & 5\end{array}$

6. I understand the respective role of medicine within an interprofessional team.

Strongly Disagree Disagree Neutral Agree Strongly Agree

$\begin{array}{lllll}1 & 2 & 3 & 4 & 5\end{array}$

7. I understand the respective role of physician assistants within an interprofessional team.

$\begin{array}{ccccc}\text { Strongly Disagree } & \text { Disagree } & \text { Neutral } & \text { Agree } & \text { Strongly Agree } \\ 1 & 2 & 3 & 4 & 5\end{array}$

8. I understand the respective role of physical therapy within an interprofessional team.

$\begin{array}{ccccc}\text { Strongly Disagree } & \text { Disagree } & \text { Neutral } & \text { Agree } & \text { Strongly Agree } \\ 1 & 2 & 3 & 4 & 5\end{array}$

9. I understand the respective role of pharmacy within an interprofessional team.

$\begin{array}{ccccc}\text { Strongly Disagree } & \text { Disagree } & \text { Neutral } & \text { Agree } & \text { Strongly Agree } \\ 1 & 2 & 3 & 4 & 5\end{array}$

10. Shared learning and working within an interprofessional team will help me communicate better with patients and healthcare professionals.*

$\begin{array}{ccccc}\text { Strongly Disagree } & \text { Disagree } & \text { Neutral } & \text { Agree } & \text { Strongly Agree } \\ 1 & 2 & 3 & 4 & 5\end{array}$

11. Shared learning and working within an interprofessional team will increase my ability to understand clinical problems.*

$\begin{array}{ccccc}\text { Strongly Disagree } & \text { Disagree } & \text { Neutral } & \text { Agree } & \text { Strongly Agree } \\ 1 & 2 & 3 & 4 & 5\end{array}$

12. Shared learning and working within an interprofessional team will help me be a more effective member of a healthcare team in the future.*

Strongly Disagree Disagree Neutral Agree Strongly Agree

$\begin{array}{lllll}1 & 2 & 3 & 4 & 5\end{array}$




\section{JRIPE}

230

Interprofessional Healthcare Elective and Student-Run Free Clinic

Shrader, Thompson, \& Gonsalves

\section{Journal of Research in Interprofessional Practice and Education}

13. Shared learning and working within an interprofessional team will help me understand my own limitations.*

$\begin{array}{ccccc}\text { Strongly Disagree } & \text { Disagree } & \text { Neutral } & \text { Agree } & \text { Strongly Agree } \\ 1 & 2 & 3 & 4 & 5\end{array}$

14. It is important to interact with teachers and preceptors from other healthcare professions.

$\begin{array}{ccccc}\text { Strongly Disagree } & \text { Disagree } & \text { Neutral } & \text { Agree } & \text { Strongly Agree } \\ 1 & 2 & 3 & 4 & 5\end{array}$

15. Patients ultimately benefit if students and healthcare professionals work in interprofessional teams to solve patient problems.*

$\begin{array}{ccccc}\text { Strongly Disagree } & \text { Disagree } & \text { Neutral } & \text { Agree } & \text { Strongly Agree } \\ 1 & 2 & 3 & 4 & 5\end{array}$

16. Using interprofessional teams to deliver quality healthcare is essential for the future.

$\begin{array}{ccccc}\text { Strongly Disagree } & \text { Disagree } & \text { Neutral } & \text { Agree } & \text { Strongly Agree } \\ 1 & 2 & 3 & 4 & 5\end{array}$

17. I am going to work in an environment that fosters interprofessional teamwork to deliver patient care in the future.

$\begin{array}{ccccc}\text { Strongly Disagree } & \text { Disagree } & \text { Neutral } & \text { Agree } & \text { Strongly Agree } \\ 1 & 2 & 3 & 4 & 5\end{array}$

* RIPLS questions 